\title{
The Epidermolysis bullosa house in Salzburg
}

\author{
Gabriela Pohla-Gubo \\ From 5th European Conference on Rare Diseases (ECRD 2010) \\ Krakow, Poland. 13-15 May 2010
}

With a reported prevalence of 4.6 per million, Epidermolysis bullosa (EB) is a rare disease comprising a clinically as well as genetically heterogeneous group of inherited mechano-bullous disorders. Minor trauma leads to blisters and erosions on skin and mucous membranes. Based on mutations in genes encoding for structural proteins of basal keratinocytes or within mucocutaneous basement membranes numerous extra-cutaneous manifestations may complicate this disease, causing multi-systemic involvement with significant morbidity and even mortality that necessitates multidisciplinary care.

The EB House Austria was founded in 2005 and forms part of the Department of Dermatology of the Paracelsus Medical University, Salzburg. The building has mainly been financed by the patient organisation DEBRA Austria and a one-time subsidy granted by the federal government. As an interdisciplinary clinical unit for diagnosis, medical care, academic affairs and research related to EB, the EB House Austria fulfils all criteria for Centres of Expertise according to the "Final Report on European Centres of Expertise (ECZ) from RDTF expert group" in 2005.

Besides treating patients from Austria, EB sufferers from 15 other countries have been visiting the EB House up to now. In the light of the proposed Directive for European Networks of Centres of Expertise, pros and cons of cross border healthcare like liaisons with the referring physicians, post-treatment care, training opportunities for foreign clinicians or reimbursement are discussed. For example for some of the neighbouring EC countries, reimbursement is well organised. For others individual solutions have been found so far.

Correspondence: g.pohla-gubo@salk.at

General Hospital, Department of Dermatology, Paracelsus Medical, Muellner Hauptstr. 48, Salzburg 5020, Austria
All the specialists of the EB House Austria collaborate closely with other major EB groups, both in Europe and worldwide, and are willing to give all EB patients a home and hope for the future.

Published: 19 October 2010

doi:10.1186/1750-1172-5-S1-012

Cite this article as: Pohla-Gubo: The Epidermolysis bullosa house in Salzburg . Orphanet Journal of Rare Diseases 2010 5(Suppl 1):012.
Submit your next manuscript to BioMed Central and take full advantage of:

- Convenient online submission

- Thorough peer review

- No space constraints or color figure charges

- Immediate publication on acceptance

- Inclusion in PubMed, CAS, Scopus and Google Scholar

- Research which is freely available for redistribution

Submit your manuscript at www.biomedcentral.com/submit 